\title{
THE INFLUENCE OF RELATIONSHIP MARKETING TOWARDS TAXPAYER'S SATISFACTION IN TAX AMNESTY PROGRAM
}

\author{
Andrian Haro \\ Faculty of Economis, State University of Jakarta \\ e-mail: andrianharo@feunj.ac.id
}

\begin{abstract}
The objective of this research is to examine the influence of relationship marketing which consist of trust, commitment, and communication toward taxpayer's satisfaction in tax amnesty program. By using the purposive sampling method, the research sample is taxpayers who have a NPWP and registered in tax amnesty program. Only $48 \mathrm{re-}$ spondents who is qualified as the research sample. Multiple liniear regression was used to analyze the data and to test the research hypotheses through SPSS. The result shows there is no influence between trust toward taxpayer's satisfaction in tax amnesty program. Meanwhile, commitment and communication have an influence on taxpayer's satisfaction in tax amnesty program.
\end{abstract}

\section{Keywords:}

trust, commitment, communication, satisfaction, tax amnesty, relationship marketing

Received: 2 Maret 2018 ;

Accepted: 14 Maret 2018;

Publish; April 2018

\section{How to Cite:}

Haro, A.. (2018). The Influence Of Relationship Marketing Towards Taxpayer's Satisfaction In Tax Amnesty Program. Econosains, 16(1), P 48-57 


\section{INTRODUCTION}

The condition of the common problems associated with tax levies in Indonesia is still a lot of people who do not want to fulfill their tax obligations to the government. The government is trying to improve national development in the next five years through a number of major projects such as the construction of tolls, land infrastructure and village revitalization and agriculture. However, the funds required by the government to finance the development project is still unfulfilled. Therefore, public pressure for the government to reduce the amount of debt, so the source of available financing is derived from tax and customs duties (Setyonugroho, 2012).

The government targets to obtain additional tax of $\mathrm{Rp} 600$ trillion in the coming year with an initial target of

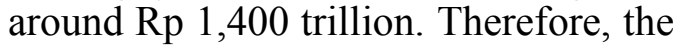
government plans to grant amnesty tax amnesty to Indonesian Citizens (WNI) who allegedly conduct tax evasion abroad (Safrina et al., 2016). This tax amnesty has nothing to do with income but relates to the increase in the value of taxpayers' assets and debts. In principle, the tax apparatus is not allowed to ask the origin of the property. With this tax forgiveness program is a great opportunity for the government in obtaining information disclosure owned by the taxpayer. Taxpayers are required to inform assets not yet reported in the previous annual SPT. Through this policy is expected to assist in increasing the number of taxpayers, tax subjects and tax objects and urge the public to improve compliance and awareness of taxpayers in participating actively to government-run programs (Pramishinta and Baldric, 2011).

Tax amnesty policy can be said not a new policy. This is because in some countries in the world, both de- veloped and developing countries have run the tax amnesty program. In 1964 and 1984, the tax amnesty policy in Indonesia was enacted. But unfortunately the results of its implementation can be said to be less successful. This is due to an inadequate taxpayer response and is not accompanied by a thorough reform of tax administration (Safrina et al., 2016). Of course the existence of this tax amnesty program can lead to pros and cons in the community where the program can be misused by the pengemplang of taxes that only affect the benefits for their side only. Thought may occur due to the low level of public confidence to the tax apparatus. Plus the rules of taxation that somewhat complicated so difficult for the community (Fatmala and Ardini, 2017).

To overcome the impact of failure that may be repeated in this program, the tax apparatus needs to socialize the tax amnesty program either in the form of counseling or technical understanding, promotion through print media (leaflets, banners and banners) in strategic places, and publications through social media (twitter, facebook, youtube, and instagram), and features of online applications or websites that can be accessed by taxpayers easily. The presence of such socialization provides knowledge to the taxpayer and causes his tax obligations to grow higher (Wardani and Erma, 2018).

In addition, the strategy that can be done by the tax apparatus in fostering and maintaining the taxpayer to be obedient to the rules and willing to participate in the offered program is to create a good relationship between the taxpayer and the tax apparatus (Susila, 2004). The term relationship is known as relational marketing (relationship marketing), which is an approach to be able to recognize taxpayers more closely through a two-way communication process by managing mutually beneficial relationships with each other 
(Apriliani et al., 2014). Therefore it can be concluded that by establishing or fostering good relationships with the taxpayers, it can determine the future value of a business or activity tax apparatus. According Ndubisi (2007) there are several factors that give influence in relationship marketing, namely trust, commitment, communication, and problem solving. Through these factors are expected to provide satisfaction for taxpayers so that it will bring a positive impact on the program offered tax apparatus. Basically the success of this tax amnesty policy will also have a positive impact in encouraging development in Indonesia as a whole.

Therefore, this study is interested to discuss about the influence of relationship marketing that includes trust, commitment, and communication in achieving taxpayer satisfaction in tax amnesty. Later on they can become taxpayers loyal and obedient to the applicable tax rules and provide income for the government not only in the short term, but for the long term (Rasbin, 2016).

Following the introduction, the second section provides a selected literature review on trust, commitment, communication, towards taxpayer's satisfaction in tax amnesty program, Research methodology are discussed in the third section, while the fourth presents research results of findings and discussions. The final section of the paper draws certain conclusions and directions for future research.

\section{LITERATURE RIVIEW}

\section{Relationship Marketing}

The meaning of relationship marketing can illustrate the various contexts and perspectives of marketing activities. A narrow definition, relationship marketing describes a variety of marketing strategies in binding or re- taining customers after a sales process, where the ultimate goal is to create repeat purchases (Chan, 2009). When viewed the meaning of relationship marketing widely, it can be interpreted a paradigm and marketing orientation as part of the opposition of transactional marketing (Widiana, 2004).

According to Kotler and Keller (2012), relationship marketing is a practice in fostering long-term relationships that can satisfy key stakeholders, such as customers, suppliers and dealers, in order to maintain the company's long-term preferences and business. Relationship marketing is a process whereby suppliers and customers develop long-term relationships based on mutual cooperation, interdependence, trust and commitment to the added value to be provided (Tower et al., 2006).

Attempts to familiarize customers deeply for the company to meet customer needs and wants in the long term are part of relationship marketing (Zeithaml et al., 2013). Relationship marketing is closely related to the service marketing sector. This can occur because of the direct involvement and interaction between customers and service providers that are high in most service business sectors (Lupiyoadi, 2013). Hence, a transaction-marketing approach with a target of high sales in a short span of time becomes less supportive of service business practices. Ndubisi (2007) suggests that in relationship marketing there are four key principles of trust, commitment, communication, and problem solving.

\section{Trust}

Trust is an important thing in a commitment or a promise, where commitment can only be realized if it can give its own meaning. Trust will occur if customers believe in the service provider and have a high degree of integrity (Arifin, 2011). According to Adji and Semuel (2014), one of the im- 
portant variables that play a role in maintaining a long-term relationship including a brand is trust. Given the long-term relationship it can increase consumer confidence in the expectations that will be received from the company. These conditions can reduce customer unrest on the services it receives. This can certainly potentially be a barrier in influencing consumers to make the selection (switching barrier). The basis of trust directly occurs when the customer performs information processing activities. Information about the attributes and benefits of products / services received, encoded into memory, and then reopened from memory for use (Rahadian, 2011).

The trust factor of the parties involved in a relationship is an indicator of relationship marketing success. Trust is a person's self-confidence found based on the desires of others earned through his own power. The target to be achieved from trust in the hope of credibility and good deeds (Riorini, 2003). To realize the success of a marketing relationship comes from trust.

\section{Commitment}

One important factor is based on the strength of the relationship of marketing through a commitment. This is because commitment is the result of a relationship that is said to be successful, giving satisfaction, and bringing benefits (Ndubisi, 2007). The company's commitment illustrates that the company's continuing relationship with its purchasers should be well maintained. While brand commitment is described as an emotional or psychological connection with a particular brand in a product class. Overall, the most frequent brand commitment in products with high engagement describes as selfconcept, value, and consumer needs. Furthermore, the concept of self and consumer needs is related to customer expectations or customer expectations
(Sulistiani et al., 2015). According to Rahadian (2011), commitment is an attitude that is the intention to maintain a long-term relationship because the relationship is felt valuable and provide benefits. Relational benefits focus on benefits derived from the services offered.

\section{Communication}

The process used by companies and customers in sharing information to achieve common interests is a communication. Communication is very important in widespread dissemination of a new product. Lupiyoadi (2013) argues that in business activities, marketing communications provide a very important role that can be said part of the marketing mix. Therefore, in order to retain customers and attract new customers, the company conducts proper marketing communications and matches the character of the intended customer.

Anderson and Narus in Ndubisi (2007) suggest that in this context, communication refers to the ability to provide timely and reliable information. Sulistiani et al. (2015) says communication as an interactive dialogue between the company and the customer, which takes place during the pre-sale stage, sales, consumption and after consumption. Communication in marketing relations means maintaining relationships with customers, providing timely and reliable information when services and services change, and communicating proactively in case of a complaint in communicating.

\section{Satisfaction}

According to Kotler and Keller (2012), customer satisfaction is the feeling of a person in the form of happy or disappointed based on the process of comparing the perceived product performance (performance) with the per- 
formance (result) of the expected product. If performance is below customer expectations, then the customer will not be satisfied. On the contrary if performance meets customer expectations, then the customer will be satisfied. In addition, customers can feel very satisfied if the product performance exceeds customer expectations. The tendency of a satisfied customer will give a good recommendation on the product or service to others. Any form of customer action against the provider of the product or service, in which an emotional reaction to the difference between the expectations and the reality they derive relating to the fulfillment of a need, purpose or desire is the meaning of satisfaction (Hansemark and Albinson, 2004). Prasasti et al. (2003) states that there are several aspects of customer satisfaction, such as service responsiveness, transaction speed, service existence, professionalism, overall satisfaction with services or services. In addition, there are five main factors that must be considered in customer satisfaction, namely product quality, service quality, emotional, price, and cost (Adji and Semuel, 2014).

The existence of relationship marketing conducted by a company is expected to create customer satisfaction. The relationship between relationship marketing and customer satisfaction is reinforced by Mudie and Cottam in Tjiptono (2011) which says that total customer satisfaction will not be achieved, even if only temporarily. But what needs to be done is the improvement and refinement of satisfaction through various strategies. One strategy that can be integrated to achieve and improve customer satisfaction is with relationship marketing.

Based on the explanation above, the hypothesis formulations stated as follow:
$\mathrm{H}_{1}$ : There is a influence between trust and taxpayer's satisfaction in tax amnesty program

$\mathrm{H}_{2}$ : There is a influence between commitment and taxpayer's satisfaction in tax amnesty program

$\mathrm{H}_{3}$ : There is a influence between communication and and taxpayer's satisfaction in tax amnesty program

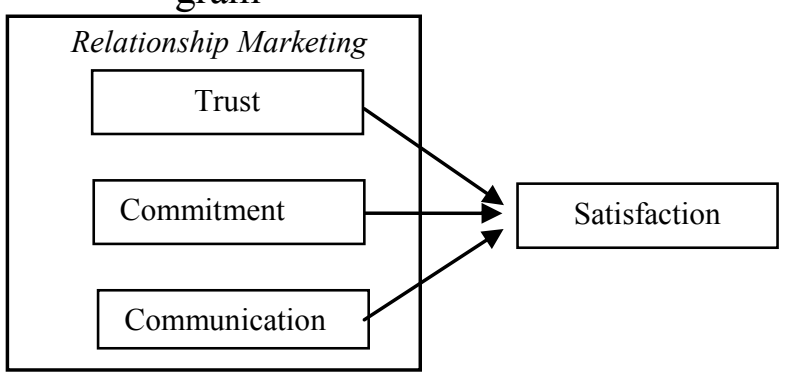

Picture 1. Research Model

Source : Data processed by researchers (2017)

\section{RESEARCH METHODOLOGY}

According to Sekaran (2006), the sample is part of the number and characteristics possessed by the population. Determination of sample according to Roscoe theory in Sugiyono (2012) stated that the sample size is feasible in the research is 30 to 500 . In this research, sampling technique used is a nonprobability sample with purposive sampling method, where this method takes a sample of population based criteria that have been determined by researchers (Santoso, 2010). The criteria that must be considered in taking this sample is the respondent is a community registered as a taxpayer is marked with ownership of Taxpayer Identification Number (NPWP) and has reported itself as a participant tax amnesty. Based on the opinion of the experts, then the number of samples according to the criteria and then will be done analysis is as much as 48 respondents taxpayers.This study used primary data sources, data collection methods used through surveys or questionnaires dis- 
tributed to a number of respondents. The questionnaire is closed in which the respondent's desired answer is available so that the respondents are expected to choose one of the available answers. Each statement submitted in this questionnaire refers to the indicators in the research variables. The scale used in this study uses 5-point Likert Scale $(1=$ Strongly Disagree and $5=$ Strongly Agree).

This data used quantitative data analysis, quantitative data analysis is a form of analysis in the form of numbers that use statistical calculations, where the data will be grouped into certain categories using various types of tables (Hair et al., 2006). For the processing and analysis of quantitative data from each test is done with SPSS 21.0 software program.

\section{Findings}

Here is the result of validity test in Table 4.3. Based on the results of validity testing showed that all items statement of each construct has a factor loadings greater than 0.50 . Thus the test results validity of all statement items in each construct can be declared valid.

Table 1. Result of Validity Test

\begin{tabular}{lll}
\hline Items & $\begin{array}{l}\text { Factor } \\
\text { Loadings }\end{array}$ & Conclusions \\
\hline Trust & 0,929 & Valid \\
X11 & 0,928 & Valid \\
X12 & 0,881 & Valid \\
X13 & & \\
\hline Commitment & 0,939 & Valid \\
X21 & 0,928 & Valid \\
X22 & 0,908 & Valid \\
X23 & 0,934 & Valid \\
X24 & & \\
\hline Communication & 0,935 & Valid \\
X31 & 0,943 & Valid \\
X32 & 0,939 & Valid \\
X33 & & \\
\hline Satisfaction & 0,872 & Valid \\
X41 & 0,901 & Valid \\
X42 & 0,891 & Valid \\
X43 & 0,899 & Valid \\
X44 &
\end{tabular}

Source : Data processed by researchers (2017)
In testing realibility, the researchers measure the reliability of a variable by looking at Cronbach's coefficient alpha which is quite acceptable, which is worth between 0.60 to 0.70 or more (Sekaran, 2006). Based on below test results show that the variable is declared reliable because the value of Cronbach's coefficient alpha is worth between 0.60 to 0.70 or more (Sekaran, 2006).

Table 2. Realibility Test

\begin{tabular}{ccc}
\hline Construct & Items & $\begin{array}{c}\text { Cronbach's } \\
\text { Alpha }\end{array}$ \\
\hline Trust & 3 & 0.894 \\
Commitment & 4 & 0.945 \\
Communication & 3 & 0.931 \\
Satisfaction & 4 & 0.899 \\
\hline
\end{tabular}

Source : Data processed by researchers (2017)

Test results of Goodness of Fit test was used the value Adjusted R2, where the value obtained by 0.744 . These results indicate that $74.4 \%$ taxpayer satisfaction variables in the tax amnesty program can be explained by the variation of the three independent variables, namely trust, commitment and communication. While the rest of $25.6 \%$ can be explained as a factor or other variables that affect the satisfaction that is not examined in this study.

Table 3. Goodness of Fit Test

\begin{tabular}{llrrr} 
& & R & Adjusted & $\begin{array}{c}\text { Std. Error } \\
\text { of the } \\
\text { Model }\end{array}$ \\
R & Square & R Square & Estimate \\
\hline 1 & $.872^{\mathrm{a}}$ & .761 & .744 & 1.685
\end{tabular}

Source : Data processed by researchers (2017)

The result of $t$ test is a test of significance to see the individual significance of the independent variables present in the model against the dependent variable. It aims to see the significance of how far the significant influence of one independent variable in explaining the variation of bound variables. Explanation of $t$ test result for each independent variable in this research as follows:

* $\quad$ The Influence Of Relationship Marketing Towards Taxpayer's Satisfaction In Tax Amnesty Program.

* $\quad$ https://doi.org/10.21009/econosains.0161.05 
Based on the result of partial calculation of the effect of trust on taxpayer satisfaction on the tax amnesty program obtained the value of regression coefficient (b) of $(+) 0.200$, where at the level of significance of $5 \%$ obtained $\mathrm{t}$-value of 0.994 with a significance value of 0.326 . Then the results of this hypothesis testing is $\mathrm{H} 0$ accepted (Hal rejected), meaning there is no influence of trust on taxpayer satisfaction in the tax amnesty program. This is because the value of significance ( $p$-value) $>$ 0.05 .

And then the result of partial calculation of the influence of commitment to taxpayer satisfaction on tax amnesty program obtained regression coefficient value (b) of (+) 0.387, where at 5\% significance level obtained t-value of 2.325 with a significance value of 0.025 . Then the results of this hypothesis testing is $\mathrm{H} 0$ rejected ( $\mathrm{Ha} 2$ accepted), it means there is influence of commitment to taxpayer satisfaction in tax amnesty program. Influence that happened is significant and positive, that is increasing of commitment, hence increasing also taxpayer satisfaction in tax amnesty program. This is because the value of significance ( $p$ value) $<0.05$ and the value of the regression coefficient is positive.

Based on the result of partial calculation of the effect of communication on taxpayer satisfaction in the tax amnesty program obtained regression coefficient value (b) of (+) 0.433 , where at $5 \%$ significance level obtained tvalue of 2.609 with a significance value of 0.012 . Then the results of this hypothesis testing is $\mathrm{H} 0$ rejected (Ha3 accepted), meaning there is a communication effect on taxpayer satisfaction in the tax amnesty program. Influence that happened is significant and positive, that is increasing of communication, hence increasing also taxpayer satisfaction in tax amnesty program. This is because the value of significance ( $p$ - value) $<0.05$ and the value of the regression coefficient is positive.

\section{Discussion}

Based on the results of tests that have been done can be explained that there is no influence between the trust of taxpayer satisfaction in the tax amnesty program. Similar research using trust variable in analyzing customer satisfaction showed the same result that belief did not significantly and positively affect customer satisfaction at Rs Darul Istiqomah Kaliwungu Kendal (Fasochah and Harnoto, 2013). This condition can occur because the quality of services integrated in the tax amnesty program is still not clearly visible by the taxpayer. In addition, the reliability of the tax amnesty program is still not reliable by taxpayers. The possibility of this factor that causes the trust does not provide the effect of satisfaction for the taxpayer.

Based on the results of tests that have been done can be explained that there is influence between commitment to taxpayer satisfaction in tax amnesty program. This influence gives a significant and positive effect on the commitment given by the tax apparatus to increase the taxpayers' satisfaction with the tax amnesty program. Similar research using variable of commitment in analyzing customer satisfaction showed a significant and positive result where the object of research conducted on customer in a Bank BRI Semarang area (Sulistiani et al., 2015). Based on the information can be explained that the good relationship and consistency of excellent service provided tax apparatus to taxpayers in the tax amnesty program helps improve their satisfaction to follow this program.

Based on the test results that have been done can be explained that there is influence between the communication of taxpayer satisfaction in the tax am- 
nesty program. This influence has a significant and positive effect on the communication skills provided by the tax apparatus to increase taxpayer satisfaction following the tax amnesty program. A similar study using communication variables in analyzing customer satisfaction showed significant and positive results where the object of the study was performed on the customer at a Pasuruan Regional Bank Jatim (Putri et al., 2014). Based on the information can be explained that the good communication skills and informative given tax apparatus to taxpayers is very important role in improving taxpayer satisfaction following the tax amnesty program. This will help taxpayers better understand tax products and services and raise their awareness and compliance with tax rules and increase their satisfaction.

\section{CONCLUSION}

Based on the results oh this study can be concluded that there is no influence between the trust on taxpayer satisfaction in the tax amnesty program, where the significance value of 0.326 ( $p$-value $>0.05$ ) and then there is influence between commitment to taxpayer satisfaction in tax amnesty program significantly and positively, where the value of significance equal to 0,025 ( $\mathrm{p}$ value $<0,05$ ) and regression coefficient value (b) equal to $(+) 0,387$. For the last there is influence between communication to taxpayer satisfaction in tax amnesty program significantly and positively, where the value of significance equal to 0,012 ( $\mathrm{p}$-value $<0,05$ ) and regression coefficient value (b) equal to (+) 0,433 .

For further research should add other variables that are not examined in this study such as problem solving, service quality, knowledge, and loyalty. In addition, the researcher recommends to use a research subject profile that is an individual taxpayer who performs free and corporate taxpayer's work.

\section{BIBILIOGRAPHY}

Adji, Jennifer and Semuel, Hatane. 2014. Pengaruh Satisfaction dan Trust Terhadap Minat Beli Konsumen (Purchase Intention) di Starbucks The Square Surabaya. Jurnal Manajemen Pemasaran Petra, Vol. 2, No. 1, pp. 1-10.

Apriliani, Fitri, Kumadji, Srikandi, and Kusumawati, Andriani. Pengaruh Relationship Marketing Terhadap Kepuasan dan Loyalitas Nasabah (Studi Pada Nasabah Bank Syariah Mandiri Kc Bandar Jaya). Jurnal Administrasi Bisnis, Vol. 17, No. 1, pp. 1-5

Arifin, Samsul. 2011. Pengaruh Kepercayaan, Fasilitas dan Kualitas Pelayanan Terhadap Kepuasan Konsumen Pada Hotel Jepara Indah. Jurnal Dinamika Ekonomi \& Bisnis, Vol. 8, No. 1, pp. 67-78.

Chan, Syafruddin. 2009. Relationship Marketing, Edisi Kelima. Jakarta: PT. Gramedia Pustaka Utama.

Fasochah and Hartono. 2013. Analisis Pengaruh Kepercayaan dan Kualitas Layanan Terhadap Loyalitas Pelanggan Dengan Kepuasan Konsumen Sebagai Variabel Mediasi (Studi Pada Rs Darul Istiqomah Kaliwungu Kendal). Jurnal Ekonomi Manajemen Akuntansi, pp. 1-23.

Fatmala, Nenin Dewi and Ardini, Lilis. 2017. Persepsi Wajib Pajak Pada Program Tax Amnesty Untuk Meningkatkan Penerimaan Pajak. Jurnal Ilmu dan Riset Akuntansi, Vol. 6, No. 8, pp. 1-15.

Ghozali, Imam. 2012. Aplikasi Analisis Multivariate dengan Program IBM SPSS 20. Semarang: Universitas Diponegoro. 
Hair, J. F., Black, W. C., Babin, B., Anderson, R. E., and Tatham, R. L. 2006. Multivariate Data Anal$y$ sis, $6^{\text {th }}$ edition. New Jersey: Prentice Hall International, Inc.

Hansemark, O. C. and Albinson, M. 2004. Customer Satisfaction and Retention : The Experiences of Individual With Employees. Managing Service Quality, Vol. 1.

Kotler, Philip and Keller, Kevin Lane. 2012. Marketing Management, $14^{\text {th }}$ Global edition. New Jersey: Pearson Education, Inc.

Lupiyoadi, Rambat. 2013. Manajemen Pemasaran Jasa. Jakarta: Salemba Empat.

Malhotra, N. K. 2012. Basic Marketing Research: Intergration of Social Media, $4^{\text {th }}$ edition. New Jersey: Pearson Education, Inc.

Ndubisi, N. O. 2007. Relationship Marketing and Customer Royalty. Marketing Intelligence \& Planning, Vol. 25, No. 1, pp. 98-106.

Putri, Ustantia Pratiwi, Suharyono, dan Abdillah, Yusri. 2014. Pengaruh Relationship Marketing Terhadap Kepuasan dan Loyalitas Nasabah (Studi Pada Nasabah Bank Jatim Cabang Pasuruan). Jurnal Administrasi Bisnis, Vol. 15, No. 2, pp. 1-9.

Pramishinta and Baldric, S. 2011. Pengaruh Layanan Fiskus Dan Pelaksanaan Sunset Policy Terhadap Kepatuhan Wajib Pajak Dalam Upaya Peningkatan Pajak. Jurnal Ekonomi dan Bisnis, Vol. 5, No. 2, pp. 173-189.

Prasasti, Dwi Rizki, Chaniago, Herizon, dan Sutarso, Yudi. 2003. Pengaruh Relationship Marketing Terhadap Kepuasan Pelanggan Dalam Industri Jasa Asuransi Jiwa. Ventura, Vol. 6, pp. 127-146.

Rahardian, Reza. 2011. Pengaruh Trust dan Commitment Terhadap Relationship Quality Studi pada Pe- rusahaan Pasangan Usaha PT. XYZ (Sebuah Lembaga Keuangan Non Bank). Artikel Ilmiah.

Rasbin. 2016. Tax Amnesty, Potensi Dana Repatriasi, dan Pembangunan di Indonesia. Majalah Info Singkat, Ekonomi dan $\mathrm{Ke}$ bijakan Publik, Vol. 8, No. 08, pp. 14

Riorini, Sri Vandayuli. 2003. Kepercayaan Pembeli terhadap Perusahaan Pemasok Dalam Hubungannya dengan Antisipasi Pembelian Diwaktu yang Akan Datang. Media Riset dan Manajemen, Vol 3, No 2, pp. 146-154.

Safrina, Noor, Soehartono, Akhmad, dan Noer, Muhamad. 2016. Analisis Penerapan Amnesty Pajak Terhadap Praktik Akuntansi Dalam Rangka Peningkatan Penerimaan Negara. Prosiding Seminar Nasional ASBIS. Banjarma$\sin$.

Santoso, S. 2010. Statistik Multivariat. Jakarta: PT Elex Media Komputindo.

Sekaran, U. 2006. Research Methods for Business: Metodologi Penelitian untuk Bisnis. Buku 1 dan Buku 2, edisi 14. Jakarta: Salemba Empat.

Setyonugroho, Hariyadi. 2012. Faktorfaktor yang Mempengaruhi Kemauan Untuk Membayar Pada Pajak Wajib Pajak Orang Pribadi di KPP Pratama Surabaya Tegalsari. Artikel Ilmiah STIE Perbanas. Surabaya

Sugiyono. 2012. Metode Penelitian Kuantitatif Kualitatif dan $R \& D$. Bandung: Alfabeta.

Sulistiani, Fitria, Farida, Naili, dan Widiartanto. 2015. Pengaruh Kepercayaan, Komitmen dan Komunikasi Terhadap Retensi Pelanggan Dengan Kepuasan Pelanggan Sebagai Variabel Intervening

* $\quad$ The Influence Of Relationship Marketing Towards Taxpayer's Satisfaction In Tax Amnesty Program.

* $\quad$ https://doi.org/10.21009/econosains.0161.05 
(Studi Pada Nasabah Bank BRI Unit Kartini Semarang). Diponegoro Journal of Social and Political of Science, pp. 1-10.

Susila, Ikhwan. 2004. Penerapan Konsep Relationship Marketing Dalam Riset Pajak. Benefit, Vol 8, No.1, pp. 66-67.

Tjiptono, Fandi. 2011. Pemasaran Jasa. Malang: Bayumedia.

Tower, J., Jago, L., dan Deery, M. 2006. Relationship Marketing and Partnerships in not-for-Profit Sport in Australia. Sport Marketing Quarterly, Vol. 15, No. 3, pp. 167-180.
Wardani, Erma Wati and Dewi Kusuma. 2018. The Effect Of Tax Socialization On Taxpayer Compliance With Knowledge As Intervening Variable. Jurnal Nominal, Vol. 7 No.1, pp. 33-54

Widiana, Erma M. 2004. Dampak Faktor-Faktor Pemasaran Relasional Dalam Membentuk Loyalitas Nasabah Pada Bisnis Asuransi. Majalah Ekonomi, Vol.14, No. 3, pp. 193-289.

Zeithaml, V. A., Bitner, M. J., dan Gremler, D. D. 2013. Service Marketing. New York: The McGraw-Hill Companies, Inc.

* $\quad$ The Influence Of Relationship Marketing Towards Taxpayer's Satisfaction In Tax Amnesty Program. 